\title{
A left ventricular aneurysm due to an occluded 'end artery' in a rare position mimicking a diverticulum
}

\author{
Adam Tucker, Harry Parissis
}

Department of Cardiothoracics, Royal Victoria Hospital, Belfast, UK

Correspondence to Adam Tucker, atuc@hotmail.com
To cite: Tucker $A$, Parissis H. BMJ Case Reports Published online: 2 January 2013 doi:10.1136/bcr-2012007838

\section{DESCRIPTION}

A 54-year-old man with typical ischaemic chest pain underwent emergency percutaneous coronary intervention for anterolateral ST elevation myocardial infarction. At this time, acute occlusion of an end artery, the intermediate branch of the left coronary artery, was identified (figure 1). A ventriculogram, right oblique view, also demonstrated dilation of the myocardium within the territory of the intermediate vessel (figure 2). At first, this was thought to be a cardiac diverticulum. The patient underwent coronary artery bypass grafting, and the diverticulum was, in fact, found to be a $3 \times 3 \mathrm{~cm}$ thin-walled ventricular aneurysm. This was successfully repaired.

Left-ventricular aneurysms are a welldocumented complication of myocardial infarction. Myocardial infarction accounts for $95 \%$ of cases. ${ }^{1}$ Usually, they are anterior-apical or inferior in origin, but rarely can occur elsewhere ${ }^{1-3}$ and often co-exist with coronary artery diease. ${ }^{3}$ We report a rare basal left-ventricular aneurysm due to occlusion of an end artery, an intermediate branch of the left coronary arterial supply.

At the time of surgery, the defect wall was found to be extremely thin, conveying a risk of fatal leftventricular free-wall rupture. Basal ventricular aneurysms are rare and provide a diagnostic dilemma, ${ }^{1}$ as seen in this case. Although not all aneuryms require surgical correction, ${ }^{1}$ basal aneurysms convey a much greater risk of rupture owing to the thinner myocardial wall in this region, and we therefore advocate repair in these cases. The patient had an uneventful postoperative recovery. Follow-up echocardiography at 3 months demonstrated no residual aneurysm.

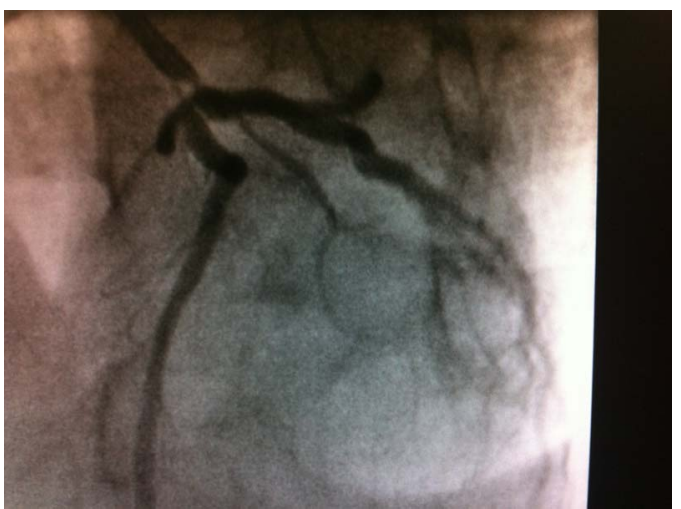

Figure 1 Coronary angiogram showing severe occlusion of the left main stem coronary artery and a small intermediate branch which is acutely occluded.

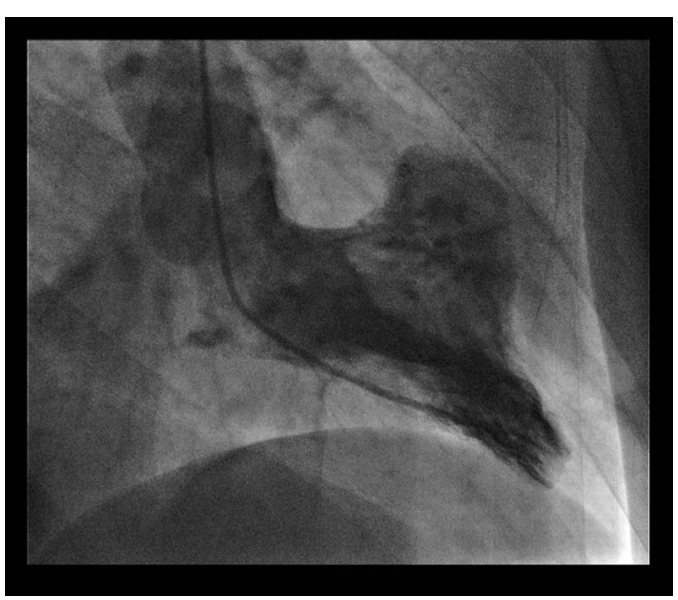

Figure 2 Right lateral oblique ventriculogram demonstrating left-ventricular aneurysm at the base of the heart in the territory of the intermediate vessel.

\section{Learning points}

Left-ventricular aneurysm (LVA) is a well-recognised entity occurring after myocardial infarction. The condition carries a significant morbidity and mortality and, under acute circumstances, may need surgical correction.

- Not all LVAs require surgical intervention, but the underlying coronary artery disease is often present which may require coronary artery bypass grafting.

- Basal aneurysms are extremely rare and they pose a diagnostic dilemma.

- Lack of adequate coronary collateralisation, together with left main stem disease, may produce 'end artery' necrosis, whereby acute ostial occlusion leads to localised myocardial necrosis and subsequently localised aneurysms.

- Basal aneurysm formation may be a direct indication of surgical repair because the myocardial wall in the area is extremely thin and the risk of rapture is high.

Competing interests None.

Patient consent Obtained.

Provenance and peer review Not commissioned; externally peer reviewed.

\section{REFERENCES}

1 Antunes MJ, Antunes PE. Left-ventricular aneurysms: from disease to repair. Expert Rev Cardiovasc Ther 2005;3:285-94.

2 Faxon DP, Ryan TJ, David KB. Prognostic significance of angiographically documented left ventricular aneurysm from the Coronary Artery Surgery Study (CASS). Am J Cardiol 1982;50:157-64.

3 Mickelborough LL, Merchant N, Ivanov J, et al. Left-ventricular reconstruction: early and late results. J Thorac Cardiovasc Surg 2004;128:27-37. 
Copyright 2013 BMJ Publishing Group. All rights reserved. For permission to reuse any of this content visit http://group.bmj.com/group/rights-licensing/permissions.

BMJ Case Report Fellows may re-use this article for personal use and teaching without any further permission.

Become a Fellow of BMJ Case Reports today and you can:

- Submit as many cases as you like

- Enjoy fast sympathetic peer review and rapid publication of accepted articles

- Access all the published articles

- Re-use any of the published material for personal use and teaching without further permission

For information on Institutional Fellowships contact consortiasales@bmjgroup.com

Visit casereports.bmj.com for more articles like this and to become a Fellow 